\title{
Characteristics of Social Entrepreneurs and How to Foster Them
}

\author{
Adrianus Tirta ${ }^{1}$, Agus Gunawan ${ }^{1,2}$, Jol Stoffers ${ }^{1,2, *}$, Dewa Gede Ngurah Byomantara ${ }^{3}$, Dewa Ketut Sujatha ${ }^{3}$ \\ ${ }^{1}$ Parahyangan Catholic University \\ Indonesia \\ ${ }^{2}$ Zuyd University of Applied Sciences, Research Centre for Employability \\ Netherlands \\ ${ }^{3}$ Sekolah Tinggi Pariwisata Nusa Dua Bali, \\ Indonesia \\ *Corresponding author's email: jol.stoffers [AT] zuyd.nl
}

\begin{abstract}
The purpose of this study is to find the characteristics that affect social entrepreneurs' level of social contribution, and what should be done to empower social entrepreneurs with the observed characteristics to fulfill the needs of social welfare in Indonesia. In total, 106 valid units-of-research from a survey with a base response number of 5,620, provided by the GEM report of 2015, are analyzed, using a multiple linear regression method to find the characteristics of the social entrepreneurs. Previous literature is used to provide suggestions for practical implication. Based on the Five Social Entrepreneurial Characteristics, it is found that the only characteristic which significantly affects social entrepreneurs' level of social contributions is perseverance. To nurture this attribute, social entrepreneurs could be driven to develop active partnerships with NGOs. Active partnerships would make social entrepreneurs develop not only perseverance, but also become more competent in contributing to social issues. This research is very specific for social entrepreneurs in Indonesia, and points to the possibilities of resorting to social entrepreneurs for fulfilling the demand of social welfare support rather than only depending on the government or NGOs. In addition, instead of encouraging the establishment of more social entrepreneurs, this research aims to foster their potential.
\end{abstract}

Keywords--- Social Entrepreneurs; Entrepreneurial Characteristics, Social Contribution

\section{INTRODUCTION}

As a developing country, Indonesia has social issues. It could be simply indicated by having $11.13 \%$ of the population or 28.01 million people living in poverty [11]. This information shows the need for social welfare support. Social welfare is defined by Business Dictionary as the well-being of the entire society that includes quality of environment, level of crime, extent of drug abuse, and availability of social services as well as spiritual aspects of life.

Aside from being maintained by the government, social welfare support is widely provided by non-governmental organisations (NGOs) [16]. However, the number of NGOs in Indonesia is still relatively small. In 2015, Smeru, a Jakarta-based independent institution for research and public policy studies, recorded around 3,000 NGOs registered in Indonesia. This is tiny compared to the number of 3,668,873 Small and Medium-Sized Enterprises (SMEs) in the nation [10].

Based on the situation, Indonesia requires additional social welfare support. Other than NGOs, business entities called Social Entrepreneurs could also give the needed assistance.

Similar with NGOs, social entrepreneurs are businesses which have social issues as one of their main concerns, shown by reinvesting their profit into social welfare support. However, separate from NGOs, social entrepreneurs do not make social welfare as their sole purpose, as they also generate other economic value $[4 ; 7 ; 12 ; 18]$. This behaviour is shown by reinvesting only a portion of their profits [17].

For instance, social entrepreneurs have different levels of social contribution, as some of them reinvest most of their profit, whereas others only reinvest a small portion of it. This research aims to find the characteristics of social entrepreneurs, which are based on the Five Social Entrepreneurial Characteristics, which affect their level of social contribution. By knowing these characteristics, the government or social institutions will be able to encourage other social entrepreneurs to give more social welfare support.

Thus, the research question is "What are the characteristics of social entrepreneurs that affect social entrepreneurs" level of social contribution?" 


\section{RESEARCH METHOD}

The sample of the research derived from respondents of the 2015 Indonesian GEM (Global Entrepreneurship Monitor) Report. All respondents from the report are entrepreneurs who actively conduct their business in Indonesia. Thus, this research filters the data to retrieve valid units-of-research, which are the social entrepreneurs that are still actively doing business. The filtering process of 5,620 total respondents from the GEM Report resulted in 176 social entrepreneurs. These data were then filtered again to ensure the validity, and finally resulted in 106 valid units-of-research.

For the method, this research uses multiple linear regression to produce the findings. Classical assumption tests that have been deployed include heteroscedasticity, multicollinearity, autocorrelation, normality, and the linearity test. Finally, this research also uses previous literature to provide recommendations for further insights.

\section{Research Model}

In their qualitative study, Ghalwash et al. [8] define social entrepreneurs as active agents who find solutions for social problems and are motivated by altruism rather than profit. It can be said that they reinvest their profit to solve social problems. The qualitative study also finds that a social entrepreneur has certain characteristics, called the Five Social Entrepreneurship Characteristics.

This study would like to quantitatively test the relation between the observed characteristics and the social-reinvestment nature of a social entrepreneur. Specifically, it will test whether all five characteristics affect social entrepreneurs' level of social contribution or not.

For identifying the level of social contribution, respondents were asked whether they agree to this statement on a scale of 1 to 5: "Profits will be reinvested to serve social or environmental purposes of my organisation". Their response to the statement became the dependent variable of the model.

With the independent variable, this current study defines five dimensions, which are based on the characteristics from the Five Social Entrepreneurial Characteristics. Ghalwash et al. [8] generates these attributes by inductively analyzing qualitative data of senior executives and industry experts. The characteristics include having an entrepreneurial mindset coded as entrepreneurial mindset, compassionate and humane attributes noted as compassion and humanitarian aspects, innovative ideas depicted as innovation, open to taking risks quantified as risk taking as well as perseverant coded as perseverance.

An entrepreneurial mindset is represented by whether the social entrepreneur operates in the market by producing goods and services, as having an entrepreneurial mindset means that the social entrepreneur creates solutions or products to address social problems or grasping social opportunities [8]. The entrepreneurial mindset helps social entrepreneurs identify new ideas and use these ideas to serve social purposes [5].

Compassion and humanitarian aspects are defined by whether the social entrepreneur is focused more on generating social value rather than generating financial profit for the organisation, as compassion and humanitarian aspects drive social entrepreneurs towards social contribution rather than simple profit [8]. The entrepreneurs' humanitarian features, which are emotions and empathy, play a significant role in the social entrepreneurial process [1].

Innovation is expressed by whether the social entrepreneur has innovative product(s), as social entrepreneurs create new kinds of products to address social issues [8].

Risk taking is characterised by whether the social entrepreneur focuses on social value or on environmental value, as there are greater and more varied risks in the social sector [8].

Perseverance is represented by whether the social entrepreneur continuously puts a substantial effort in measuring its impact, as perseverance is indicated by whether the social entrepreneur persists despite the difficulties they face [8]. Because social issues do not easily nor instantly vanish [3], continuously putting substantial effort into keeping track of the progress means that social entrepreneurs do not take social contribution as a one-time thing, showing that they are serious in solving the issues they focus on. 


\section{RESULTS}

Following the research model, the multiple regression results are depicted below.

Coefficients $^{a}$

\begin{tabular}{|c|c|c|c|c|c|}
\hline Model & $\begin{array}{l}\text { Unstandardised } \\
\text { coefficients }\end{array}$ & & $\begin{array}{l}\text { Standardised } \\
\text { coefficients }\end{array}$ & $\mathrm{t}$ & Sig. \\
\hline & B & $\begin{array}{l}\text { Std. } \\
\text { Error }\end{array}$ & Beta & & \\
\hline (Constant) & 1.196 & .438 & & 2.733 & .007 \\
\hline $\begin{array}{l}\text { Compassion and humanitarian aspects: For my } \\
\text { organisation, generating value to society and the } \\
\text { environment is more important than generating financial } \\
\text { value for the company }\end{array}$ & .095 & .102 & .094 & .938 & .351 \\
\hline $\begin{array}{l}\text { Risk taking: My organisation puts more emphasis on } \\
\text { social value than on environmental value }\end{array}$ & -.002 & .091 & -.002 & -.020 & .984 \\
\hline $\begin{array}{l}\text { Entrepreneurial mindset: My organisation operates in } \\
\text { the market by producing goods and services }\end{array}$ & .108 & .084 & .138 & 1.287 & .201 \\
\hline $\begin{array}{l}\text { Innovation: My organisation offers products or services } \\
\text { that are new to the market }\end{array}$ & .099 & .085 & .118 & 1.153 & .252 \\
\hline $\begin{array}{l}\text { Perseverance: My organisation puts substantial effort in } \\
\text { measuring its social or environmental impact }\end{array}$ & .406 & .103 & .383 & 3.933 & .000 \\
\hline
\end{tabular}

a. Dependent Variable: Profits will be reinvested to serve the social or environmental purpose of my organisation.

Despite the five characteristics defined in the model, the only characteristic that significantly affects the level of social contribution is Perseverance. The relationship between Perseverance and a social entrepreneurs' level of social contribution shows a positive correlation.

\section{Exploratory Reasons}

\section{DISCUSSION}

Social issues are usually complex and lengthy, making them neither easily nor instantly vanish [3]. Thus, to contribute meaningfully, social entrepreneurs needs strong competencies and also perseverance. Not having a sufficient level of perseverance, social entrepreneurs could get hindered in acquiring competencies needed, thus making them unable to manage social issues effectively. Failing to manage these issues would make them feel as if they are not contributing meaningfully. As companies need to feel that they have aided the society through their social support [2], failure could discourage them in continuing to provide more support. Thus, perseverance is likely to support social entrepreneurs' successes in managing social issues, leading them to give more social welfare support.

On the other side, there are thoughts as to why the other four characteristics are found not to affect the level of social contribution. In general, the other four characteristics are viewed as the attributes that an entrepreneur needs to start a social venture, but it is only Perseverance that keeps social entrepreneurs continuing this contribution [8]. Perseverance is believed to give social entrepreneurs the needed endurance to keep providing social contributions while remaining positive [13]. Phills et al. [14] also supports this argument by suggesting that perseverance is a common trait of effective social entrepreneurs. Thus, the reason why the other four characteristics do not affect the level of social contribution is that they are only affecting entrepreneurs at the beginning of the social venture, and not in keeping the social venture active.

\section{Fostering the Characteristics}

With Perseverance already noted as the affecting characteristic, this research would like to elaborate on how to foster it. Some researchers [2; 9] have found a way that is believed to be able to foster this attribute, that is, by engaging in an active partnership with NGOs. Their research suggests that being engaged in an active partnership with NGOs will encourage organisations to have not only perseverance, but also necessary competencies in dealing with social issues, which are social competencies, social measurement competencies and business competencies. Below are analyses on how the partnership fosters perseverance and the aforementioned competencies.

\section{Fostering Perseverance and Social Competencies}

Social issues are generally multifaceted, with many social entrepreneurs failing to perfectly deal with these issues and eventually changing into a more financially focused outlook [2]. Thus, social entrepreneurs need to make sure that they can manage the issues effectively despite the gap between the acquired and the needed competencies. 
Partnership with NGOs will ensure that the gap is filled, as NGOs have the required competencies to manage social issues as a result of their experience. However, the important part is that in order to transfer the competencies to the social entrepreneurs, they have to be engaged actively with the projects. Thus, they must not act only as funding bodies. By being actively engaged, the social entrepreneurs will acquire the competencies needed to eventually manage the issues independently. In fact, not only social entrepreneurs, but NGOs also acquire as well as develop their competencies by being continuously and actively engaged in social projects, as they become connected to the social issues at the grassroots level [6].

\section{Acquiring Competencies in the Social Measurement System}

Other than effectively and efficiently achieving the objectives of social projects, partnerships with NGOs will fill the gap of measurement capabilities. The measurement of NGO partnerships has to consider both financial and social impacts on input, output, and impact level [9]. However, financially focused organisations usually do not have the expertise to measure social and environmental progress, and thus partnering with NGOs becomes necessary [9; 15]. Also, as measuring social impacts is an additional skill, partnering actively with NGOs would enable social entrepreneurs to acquire competencies needed in setting measurement systems.

\section{Fostering Business Competencies}

NGOs are organisations with huge business networks, as most of them are interdependent in conducting their activities [16]. By getting in an active partnership with NGOs, social entrepreneurs would be exposed to other organisations during collaborations, and cooperating is one of the significant factors leading to business expertise such as innovation.

\section{CONCLUSION}

From the Five Social Entrepreneurial Characteristics [8], the characteristics of entrepreneurs who give social contributions by reinvesting their profit (hence social entrepreneur), it has been shown that only 1 of them actually affects the level of social contribution. The five characteristics from the previous study are originally generated by inductively analysing qualitative data of senior executives and industry experts, whereas this study tests the characteristics quantitatively using the multiple linear regression method.

The only influential characteristic is Perseverance. Analysing this further, the previous study by Ghalwash et al. [8], backed by other studies [13; 14], viewed Perseverance as the only attribute of the Five Characteristics that affects social entrepreneurs' performance. This is due to the fact that the other four characteristics only affect entrepreneurs when starting social ventures. Since the other four only play a role in encouraging entrepreneurs to start social ventures, it is understandable that they do not affect social entrepreneurs' level of contribution, as contribution is only generated after the businesses are established.

\section{Recommendations for Future Research}

This study found that Perseverance is the only characteristic that affects social entrepreneurs' level of social contribution. However, the data is still based on the respondent's perception, as this study did not use the exact data of their profit reinvestment percentage, but instead incorporated multiple choice surveys from the respondents. Thus, even though extreme answers like 1 or 5 are accurate, the other answers might be affected by the respondents' perspective of the ideal proportion of profit reinvestment.

Furthermore, this study finds Perseverance as the only affecting characteristic encouraging social entrepreneurs to acquire the competencies needed in the social sector. We believe that this finding should be tested further in order to ascertain whether the other four characteristics do not really play any role in encouraging social entrepreneurs to acquire further competencies. If it is found otherwise, then there must be another reason that makes perseverance the only characteristic which affects social entrepreneurs' level of social contribution.

\section{Practical Recommendations}

Based on the previous studies, active partnerships with NGOs is believed to lead social entrepreneurs to contribute more to social issues. However, what should be done to initiate the partnership between them? One thing to be noted is that most NGOs are open for partnership, as they do not only push organisations to meet social expectations, but also thrive to broaden the corporate social responsibilities expectations [2].

Thus, an effective starting move is by providing a place for them to frequently meet. The government or social institutions could set up an open forum that would attract both parties. The form itself may vary. It could be a seminar, a workshop, or even a formal training course about managing social issues. The key component is to make sure that the atmosphere is ideal for good communication. By providing a channel for deep conversations, the beginnings of joint initiatives would have opportunity to thrive. 


\section{REFERENCES}

[1]. Austin, J., Stevenson, H. \& Wei-Skillern, J. (2006). Social and Commerical Entreprenurship: Same, Different, or Both? Entrepreneurship Theory and Practice, 30(1), 1-22.

[2]. Burgos, S. (2012). Corporations and Social Responsibility: NGOs in the Ascendancy. Journal of Business Strategy, 34(1), 21-29.

[3]. Dale, J. M., \& Dulaimi, M. F. (2016). Cultural Competence: A Success Factor in NGO Projects? Built Environment Project and Asset Management, 6(2), 232-246.

[4]. Dees, J. G. (1998). The Meaning of Social Entrepreneurship. Retrieved on 08-16-2018 from https://entrepreneurship.duke.edu/news-item/the-meaning-of-social-entrepreneurship/

[5]. Doherty, B. \& Thompson, J. L. (2006). The Diverse World of Social Enterprise: A Collection of Eight Social Enterprise Stories. International Journal of Social Economics, 33(5/6), 361-375.

[6]. Fitzpatrick, T., \& Molloy, J. (2014). The Role of NGOs in Building Sustainable Community Resilience. International Journal of Disaster Resilience in the Built Environment, 5(3), 292-304.

[7]. Fulton, K., \& Dees, G. (2005). The Past, Present, and Future of Social Entrepreneurship: A Conversation with Greg Dees. New Paltz (NY): Gathering of Leaders.

[8]. Ghalwash, S., Tolba, A., \& Ismail, A. (2017). What Motivates Social Entrepreneurs to Start Social Ventures? An Exploratory Study in The Context of a Developing Economy. Social Enterprise Journal, 13(3), 268-298.

[9]. Hansen, E. G., \& Spitzeck, H. (2011). Measuring The Impacts of NGO Partnerships: The Corporate and Societal Benefits of Community Involvement. Corporate Governance: The International Journal of Business in Society, 11(4), 415-426.

[10]. Indonesia Statistics (2015). Indonesia: Statistics \& Facts. Retrieved on 16-08-2018 from https://www.statista.com/topics/2398/indonesia/

[11]. Indonesia Statistics (2016). Indonesia: Statistics \& Facts. Retrieved on 16-08-2018 from https://www.statista.com/topics/2398/indonesia/

[12]. Leadbeater, C. (1997). The rise of the social entrepreneur. Demos, 25.

[13]. Omorede, A. (2014). Exploration of Motivation Drivers towards Social Entrepreneurship. Social Enterprise Journal, 10(3), 239-267.

[14]. Phills, J. A., Jr., Deiglmeier, K., \& Dale, M. T. (2008). Rediscovering Social Innovation. Stanford Social Innovation Review, 6(4), 34-43.

[15]. Points of Light Foundation (PLF) (1999). Building Value: The Corporate Volunteer Program as a Strategic Resource for Businesses, Points of Light Foundation. Washington, DC: Author.

[16]. Scanlon, M. M., \& Alawiyah, T. (2015). The NGO Sector in Indonesia: Context, Concepts and an Updated Profile [Report]. London, UK: Cardno.

[17]. Tan, W. L., Williams, J. \& Tan, T. M. (2005). Defining the Social in Social Entrepreneurship: Altruism and Entrepreneurship. International Entrepreneurship and Management Journal, 1(3), 353-365.

[18]. Zahra, S. A., Gedajlovic, E., Neubaum, D. O. \& Shulman, J. M. (2009). A Typology of Social Entrepreneurs: Motives, Search Processes and Ethical Challenges. Journal of Business Venturing, 24(5), 519-32. 